\title{
Management Practices of Pasture, Range and Grazing Reserves for Livestock Production in the Tropics: A Review
}

\author{
Kubkomawa Hayatu Ibrahim ${ }^{1, ~ *, ~ L a w a l ~ A b u b a k a r ~ U s m a n ~}{ }^{2}$ \\ ${ }^{1}$ Department of Fisheries Technology, Federal Polytechnic, Mubi, Nigeria \\ ${ }^{2}$ Department of Animal Health and Production Technology, Federal Polytechnic, Mubi, Nigeria
}

Email address:

kubkomawa@yahoo.com (K. H. Ibrahim)

${ }^{*}$ Corresponding author

To cite this article:

Kubkomawa Hayatu Ibrahim, Lawal Abubakar Usman. Management Practices of Pasture, Range and Grazing Reserves for Livestock Production in the Tropics: A Review. American Journal of Entomology. Vol. 5, No. 2, 2021, pp. 18-26. doi: 10.11648/j.aje.20210502.11

Received: April 20, 2021; Accepted: May 5, 2021; Published: May 14, 2021

\begin{abstract}
The objective of the paper was to review management practices of pasture, range and grazing reserves in order to ensure steady supply of feed and promote sustainable livestock productivity in the tropics. Grazing management deals with such questions as how long should animals stay in one area and how long they should stay off it; which animals should graze what pasture; how many animals should graze together and what other activities should be integrated with grazing. Grazing management and stocking rate are the two most important variables affecting herbage production, seasonal pattern of production, herbage quality and botanical composition. Farm animals require nutrients to support body maintenance, reproduction, lactation, and growth. The nutritional needs of livestock vary according to breed, age, sex, class, stage of production, performance level and weight. Physiological and environmental stressors, such as sickness and weather, can also influence nutritional requirements. Ruminant animals, especially cattle, sheep and goats are natural grazers and possess remarkable ability to digest plant carbohydrates that is generally indigestible by most other mammals. It is natural then to assume that, grazing is the best way to supply a nutrient-dense diet to ruminant animals. Pasture land with high quality grasslegume can meet energy requirements of growing or lactating ruminants in the wet season. Energy supplementation on pasture helps in maintaining high grains and milk production. High quality forages have the ability to supply all the energy needed to maintain highly-productive ruminants throughout the growing season, but only when managed intensively. Legume-grass pastures have protein content greater than $18 \%$ during the vegetative stage. Feed resources that contain minerals include; range or pasture plants, harvested forages, concentrates and mineral supplements. The levels of minerals in plants are a function of interaction between several factors which include soil type, plant species, stage of maturity, dry matter yield, grazing management and climate. Forage conservation and preservation should be highly encouraged among farmers especially during the wet season where the feed resources are in abundant supply.
\end{abstract}

Keywords: Management Practices, Pasture, Range, Grazing Reserves, Livestock, Tropics

\section{Introduction}

According to Federal Ministry of Agriculture and Water Resources, FMAWR [10], Nigeria has a land area of 92.4 million hectares of which about $44 \%$ are under permanent pastures that supports its domestic ruminants of over 101 million. It is estimated that, only about $3 \%$ of this number of animals are reared on improved pastures (intensive management); the remaining $97 \%$ are raised on low nutrient native pastures and farmlands (under extensive management) as described by Okorie and Sanda [18]. According to Kallah [12], grazing lands in Nigeria, including natural wetlands (fadama), grass and woodlands and forest reserves are estimated to cover about 32.42 million hectares, while cultivated crop-lands amount to about 39.41 million hectares. These lands provide substantial amount of forage and fodder as major sources of feed for the country's ruminant livestock, both domestic and wildlife $[12,10,16]$. 
In Nigeria, forage quality and availability vary greatly from season to season, which affects the output of the animals [19]. The nutritive value of pastures fall rapidly with maturity and during the dry season the available feed is lignified [19]. Likewise, protein, nitrogen, sulphur, vitamins and other nutrients are limited in grassland pastures during the dry season, while fibre is high with dry matter content of more than $30 \%$. The nutritive value of any feedstuff is determined by its chemical composition and its digestibility and this is related to the forage and its environment. The rate of acceptability of forage is related to the readiness to which the forage is selected and consumed [19].

In spite of the infertile soils and hostile climatic environment, ruminant livestock survival in Northern Nigeria largely still depends on the extensive native pastures, browses and crop residues found across and within the various agro-ecological zones [21, 17, 11]. Nigeria's forage and fodder species vary widely and are spread across the major agro-ecological zones of the country [21, 17, 11]. Extensive areas of Nigeria's grazing lands are composed of indigenous forage species with their various botanical characteristics. Most of the species grown, until recently, are of the indigenous or local varieties that often have very low yields $[20,15]$. Long periods of cropping, rough topography and frequent bush burning, among other factors, have given rise to mixed tree, shrub and grass vegetation in the savannah zones of the country $[20,15]$. The grasses are composed of both annuals and perennials, and the trees show features characteristic of plants growing in low rainfall areas $[20,15]$. Various nutrients and minerals, such as nitrogen, phosphorus and potassium among others, have also been found to be a key limiting factor in the proper development of forage and fodder crops, and hence the efficient utilization of these crops by livestock $[20,15]$. The objective of the paper was to review management practices of pasture, range and grazing reserves in order to ensure steady supply of feed and promote sustainable livestock productivity in the tropics.

\section{How to Avoid Damage to Forage Crops}

Research has shown that, to avoid damage to forage crops, the farmer need to put the following factors into consideration: adjust stocking rate, defer grazing after several weeks upon onset of rains to enable plants recover next grazing, allow pasture a period of rest, avoid cyclic rest period, there should be no rigid timing for pasture resting [2, $3,21,15]$.

\subsection{Laws/Regulations of Successful Grazing}

Before a sward sheared by animal teeth can achieve its maximum productivity, sufficient time interval must elapse between two successive shearing to allow grasses to accumulate reserves necessary for growth and to produce its blaze of growth [2]. Total occupation of one paddock should be sufficiently short enough for the grass sheared on the first day or cut at the beginning of occupation not to be cut again by the teeth of the animals before they leave the paddock (Maximum of 6days is required). Strip grazing becomes important here to avoid re-growth being grazed [2]. Animals with the greatest nutritional requirements must be helped to harvest the greatest quantity and quality of grasses possible. If a cow must give a regular milk yield, she must not stay longer than three days in the same paddock. Yield should be at maximum if the cow stays on one paddock for one day [3, $20,15]$.

\subsection{Factors that Affect the Condition of Pasture, Range and Grazing Reserves}

The first requirement for the pasture, range land and grazing reserve manager is an understanding of the various factors affecting grass land change in his local area, and the signals which indicate whether the changes occurring are beneficial or harmful $[20,13,15]$. The factors which define the local ecosystem are the characteristics of the physical environment such as climatic, edaphic (soil) and physiographic factors. Secondly, there are biotic influences such as the natural fauna of the area, domestic grazing animals, burning, clearing and other modifications made by $\operatorname{man}[20,13,15]$.

\subsubsection{Climatic Factors}

Climate is one of the most important factors which determine the type of grazing land [9]. Generally, the wetter the climate is, the denser the vegetative cover [9]. Climate has had an important influence on the evolution of the tribes of gramineace. The Andropogon produce more species in the warm monsoon type climate with a wet/dry season [14]. They have their apparent centre of distribution in South-East Asia and include Andropogon, Hyparrhenia, Imperata and Sorghum. The paniceace are, also, a warm climate tribe, their distribution is greater in areas of high annual rainfall. They appear to have originated in the western hemisphere. The principal genera include Axonopus, Brachiaria and Pennisetum. By contrast, the erogrosteae are best developed in semi-arid and arid regions of the tropics. This tribe include Dactylocterium, Erogrostis, Leptochloa and Tripogon. Two other major tribes, the Agrosteae and Festuleae, are characteristic of temperate regions eg Agrostis, Festuca, Vulpia which occur in the cooler climates, often found in areas of high altitude. Fluctuations in climate from year to year may cause radical changes in species composition of grass-land. For example, the Eastern Margin in Central Queensland of the Mitchell grass may become invaded and dominated by Dichanthium sericeum if successions of abnormally wet years occur. A period of below normal rainfall causes the recession of $D$. sericeum, and its eventual replacement by Astrebla (Mitchell Grass) spp. The composition of grass-land is never static and is especially influenced by catastrophic events [1, 20, 13, 15].

\subsubsection{Edaphic and Physiographic Factors}

Soil formation is controlled by climate and by parent 
material. Often the association of particular pasture communities with a certain soil type is simply the result of differences in the moisture availability of that soil $[20,13,15$, 7]. The occurrence of treeless Astrebla down in Queensland on deep cracking clay soils and of Aristida wood-lands on sandy laterite soils is probably a reflection of the more moist state of the latter. However, the association between pasture community and soil type is often useful in classification in India, the main grass-land types of Sehima/Dichanthium and Dichanthium/Cenchrus are associated with black soils and with sandy loams, respectively [20, 13, 15, 7].

True grass-lands sometimes develop on marshy land with poor drainage, which is too unfavorable for the growth of trees or shrubs. Examples are sedge swamps in coastal North Queensland; Loudetia association in Central Africa on sandy soils with poor drainage and Phragmites/Saccharum grasslands in India. Leersia hexandra is a very valuable pasture grass in many flooded situations. Seasonally flooded grasslands are a major source of grazing in some regions, for example, the llanos in Orinocobasim of Venezuela, South Sumatra and Kalimatan in Indonesia. Similarly, very saline conditions may promote herbaceous cover rather than forest $[20,13,15,7]$.

Slope and altitude modify the micro-climate of the sward, and are responsible for some interesting differences in plants distribution. In the Southern hemisphere, north facing slopes are warmer and drier than south facing slopes [20, 15].

The reverse is true in the Northern hemisphere. Altitude exerts profound effects on climate, very high altitude equatorial regions in the north of South America and East Africa can exhibit a mainly temperate climate flora $[20,15]$.

\subsubsection{Fire/Burning}

Fire-induced grass-land types are common throughout the tropical world. Many woody plants, for example Terminalia and combretum Spp, in Africa are killed by fire, and repeated burning leads to a herbaceous cover $[20,13,15,7]$ The tall rhizomatous grass Imperata cylindrica has become the dominant species on many sloping humid and subhumid, low-fertility lands of South-East Asia and Africa, as a result of repeated burning. In some cases, this was associated with slash and burn agriculture, in which the forest is hand felled, burnt, and crops planted in the ashes. After a short cropping cycle of one to three years, the forest is allowed to regenerate for 3 to 20 years. A short cycle of use may eventually lead to permanent suppression of the forest and dominance of Imperata cylindrica. Treeless uplands occur extensively in the humid and sub-humid tropics as the end point of shifting cultivation practice, in which high population density has led to an exploitative short term bush fallow [20, 13, 15].

In central coastal and sub-coastal Queensland, a combination of partial clearing, fire and grazing has displaced Themeda australis and other species as the understory of the Eucalyptus wood-lands. Established plants of $H$. contortus are more fire resistant and seedling regeneration after burning is more efficient. Partial clearing leads to the growth of more grass cover and a consequent increase in the frequency and severity of the fires possible $[20,13,15,7]$.

Deliberate burning was practiced to remove surplus old grass for convenience of mustering stock and hunting and in the hope that additional green grass growth would be stimulated $[20,13,15,7]$.

Burning in the mid-dry season seems to cause greater damage to valuable herbage species, more discontinuity of forage supply and greater vulnerability to soil erosion than burning when the soil is moist $[20,15]$.

\subsubsection{Land Clearing}

Man removes trees and shrubs to provide him with fuel and shelter and to supply various industrial needs. The land may be replanted or allowed to revert to forest; alternatively it may be cleared for cultivation or provide more grazing, some time with disastrous results [20, 15].

The amount of pasture available for grazing and the amount of tree foliage is related to the density of tree cover. The higher the tree density, the greater the yield of tree foliage but low tree density favours bigger trees to develop more foliage. The amount of pasture available is low at high tree density $[20,13,15,7]$.

Destruction of edible trees and shrubs lowers the stock carrying capacity of some dry regions. For instance, in the Sahel and Sudan Zones of Africa, browse is a most important fodder source for domestic livestock and provides green leaf for longer periods of the year than is supplied by the low growing herbage species. Browse inaccessible to livestock may be hand-cut and fed to the animals during the dry season $[20,15]$.

\subsubsection{Grazing}

The grass-lands of Africa, which have evolved undergrazing by a natural ruminant population, are generally of higher quality than the grass-lands of Australia, which developed under very limited marsupial grazing $[20,13,15$, 7]. The increased grazing pressure caused by the introduction of domestic animals has caused very great changes in grassland communities. Some have been destroyed absolutely and others have been improved by skilled manipulation of livestock $[20,13,15,7]$.

The botanical composition of grass-land reflects current and previous grazing pressure. For instance, when the Dichanthium/Cenchrus grass-land type in India is subjected to grazing on loose textured soils, the more palatable Dichanthium annulatum is lost from the sward and Cenchrus ciliaris and Lasiurus Sindicus become dominant [20, 13, 15, 7]. As grazing pressure is further increased, the sward becomes dominated by the low growing Stoloniferous cynodon dactylon and by Eleusine compressa which are unpalatable weeds. Only the unpalatable weeds remain [20, $15]$.

\subsubsection{Other Human Activities}

Some human activities like cultivation of land for crop production, burning, weeding, road construction, 
urbanization and mining have disturbed natural vegetation giving opportunity to colonized plants with high tolerance to unfavourable conditions, for example mineral toxicity and pollution, to flourish $[6,20,15]$.

\section{Evaluation of Pasture, Range and Grazing Reserves}

Methods of measuring quantity and nutritive values of forages include:

\subsection{Botanical Composition of Grass-land}

This is measured by either using point quadrant or square quadrant $[4,13])$. Point quadrant is a wooden square with holes. Metal rods of the quadrant protrude from the holes either vertically or at $45^{\circ}$. The quadrant is taken to the field and placed to the ground level. The number of plant species is observed and as many of each species that touch the metal rod are counted as shown in figure 1. If guinea grass touches it 6 times it is $60 \%$. This is determined randomly for the other plant species and final averages are obtained. They are then oven-dried after sorting to obtain dry matter yield. Each of these are then expressed as dry matter in $\mathrm{kg} / \mathrm{ha}$. The nutritive qualities are then determined by chemical analysis and digestibility trials $[20,15]$. All figures are that of internet pictures.

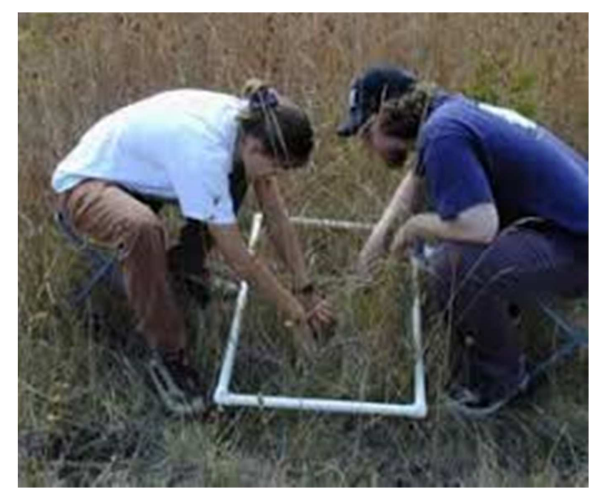

Figure 1. Point or square quadrant (Source: Google Photo).

\subsection{Measurement Based on Quantity and Quality of Forage Available to Animals}

Herbage is harvested and weighed after splitting the grazing area into units. The weight is expressed in dry matter yield per hectare. To protect plots during grazing, wire mesh is used in order to determine the quantity of herbage consumed by the animals, a measured portion of the pasture plot is ear marked. Total amount of herbage available is harvested by clipping and dry matter determined $[6,20,13,15]$. The unconsumed residue left after grazing is also determined. The differences between the two gives a good estimate of herbage consumed. Nutritive values are determined by proximate analysis and digestibility trials.

\subsection{Undesirable Plants in Pasture, Range or Grazing Reserves}

All the weeds and woody plants that are poisonous, unpalatable and/or indigestible are considered undesirable plants. Over-or under-grazed pastures are characterized by poaching, trampling, soil compaction and erosion, leading to deterioration of the pasture or forage crops. The under-grazed plants will grow forming woody plantation with little or no nutritive value to the animals $[20,13,15]$.

\section{Methods of Pasture Improvement}

The task of improving a pasture depends on the farmer's skill and knowledge $[6,20,13,15]$. Some of the practices include:

\subsection{Rotational Grazing}

Animals tend to select the most palatable herbage first. This causes excessive grazing of some species, which in turn leads to loss of regenerative power, death and soil erosion. This can be prevented by fencing off the pasture into plots and the animals rotated between periods of rest $[6,20,13,15]$ as shown in Figure 2.

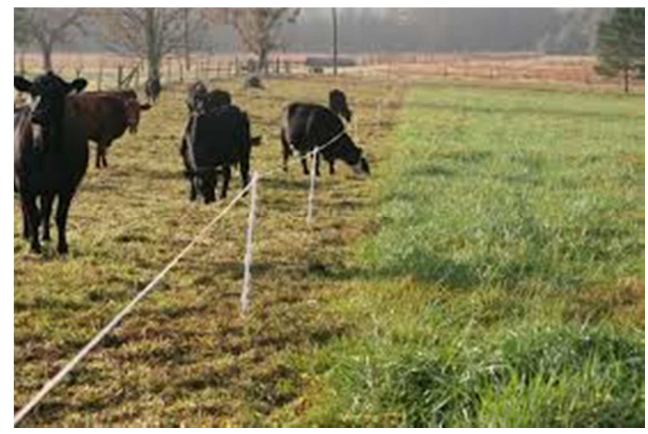

Figure 2. Rotational Grazing System (Source: Google Photo)

\subsection{Re-seeding}

Where plant population has decreased appreciably, seeds may be sown through drilling or broadcasting at the beginning of the rainy season to replace the destroyed forage crops in the pasture as can be seen in Figure 3 [8].

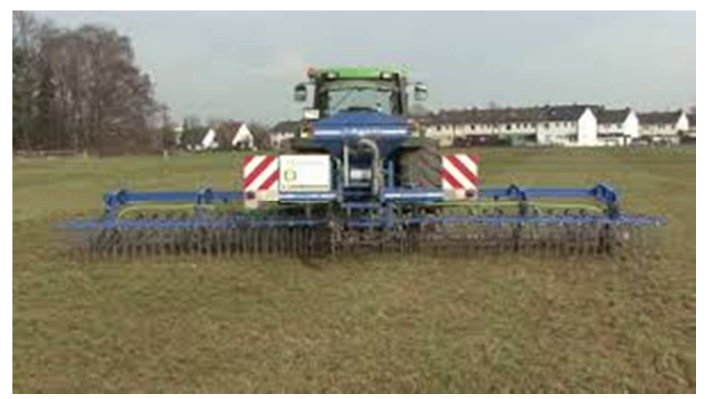

Figure 3. Mechanized Re-Seeding of Pasture Land (Source: Google Photo).

\subsection{Irrigation}

During the dry season, application of water ensures 
luxuriant growth and availability of feed throughout the year $[6,20,13,15]$. The water applied will provide moisture to the forage crops in a pasture preventing them from drying up due to excessive transpiration (Figures 4 and 5).

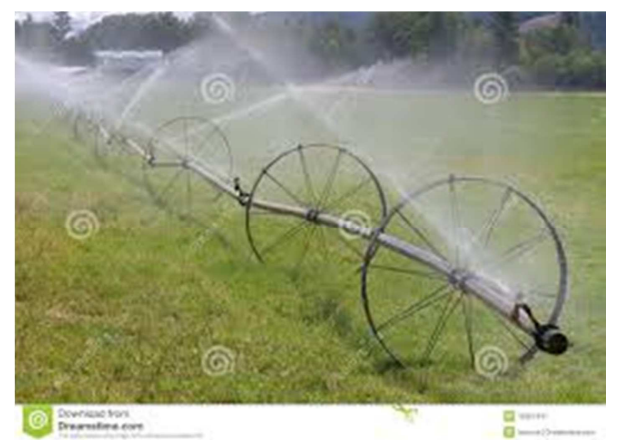

Figure 4. Wheel Line Irrigation System (Source: Google Photo).

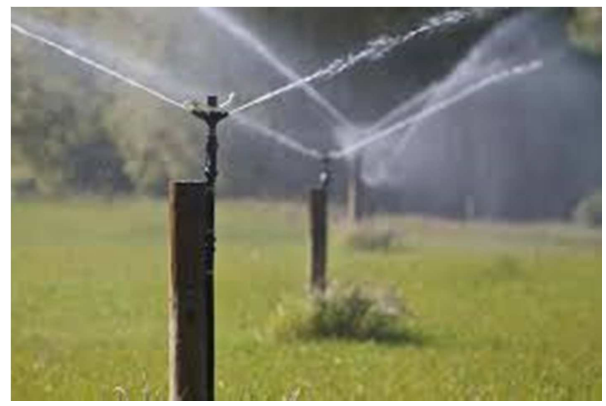

Figure 5. Fixed Sprinkler Irrigation System (Source: Google Photo).

\subsection{Fertilizers}

Applications of fertilizer at the beginning of the rains, also, ensure luxuriant growth of the forage crops [5]. The fertilizer applied will improve the soil fertility, thereby encouraging plant growth as shown in Figures 6 and 7.

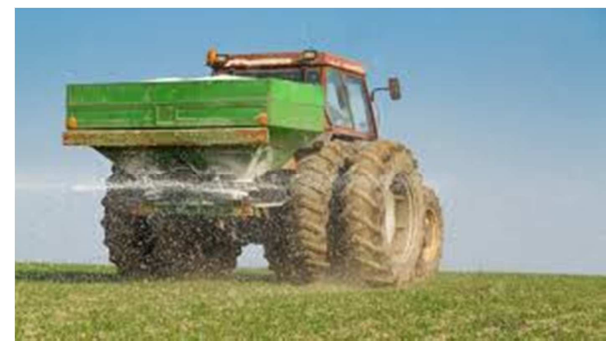

Figure 6. Mechanized Fertilizer Broad Casting System (Source: Google Photo).

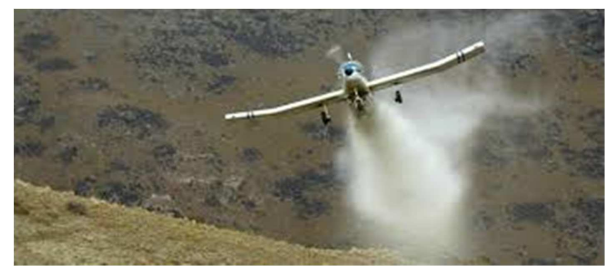

Figure 7. Aerial Fertilizer Application System (Source: Google Photo).

\subsection{Deferred Grazing}

Following over-grazing of a pasture, it might be necessary to close it to animals until it has regenerated [2].

\subsection{Weed Control}

Weeds should be removed at all times. This can be achieved by either herbicides or mechanical or manual weeding [8]. Where close planting is done, weeds pose less threat as can be seen in Figure 8.

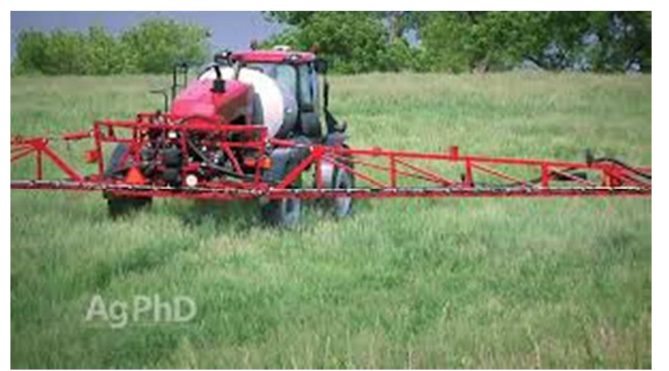

Figure 8. Mechanized Herbicide Application System (Source: Google Photo).

\subsection{Fencing (Use of Enclosures)}

Fencing enables the farmer to practice rotations and deferred grazing. It, also, prevents stray animals from grazing on the pasture $[6,20,13,15]$. The fencing can be done by the use of stones, plants or electric wires as shown in Figures 9 and 10 .

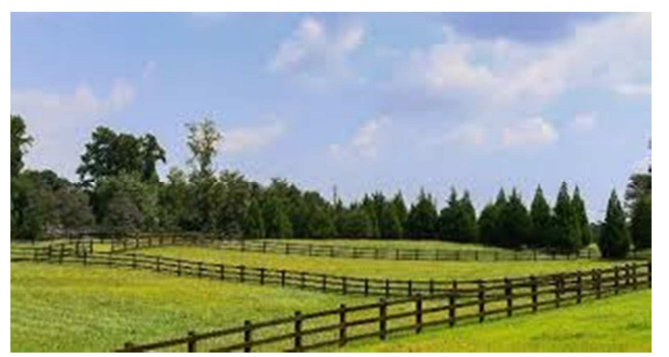

Figure 9. Fencing of Pasture Land Using Iron Bars (Source: Google Photo).

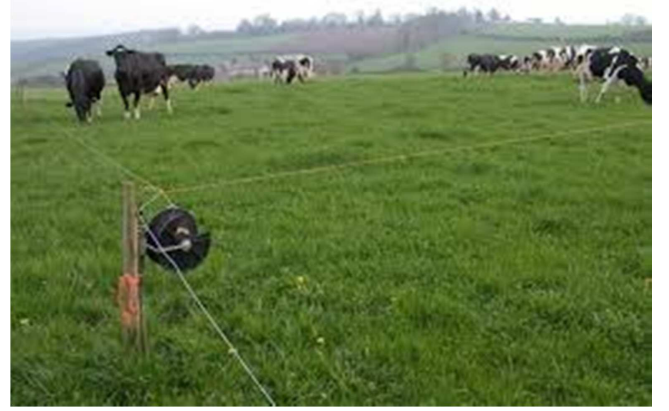

Figure 10. Fencing of Pasture Land Using Electric Wire (Source: Google Photo).

\subsection{Pest and Disease Control}

Occasional spraying during rest periods or deferred grazing helps to control pests and diseases [8]. Pesticides are used to control pests as shown in Figures 11 and 12. 


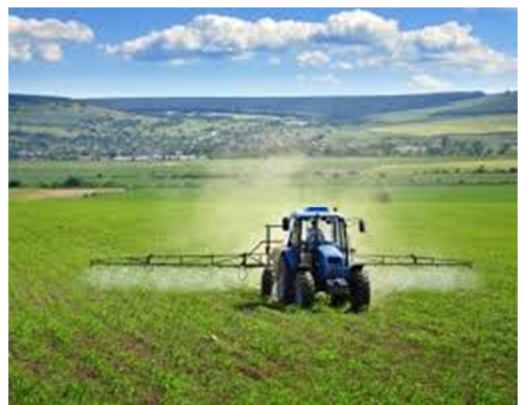

Figure 11. Mechanized Pest Control System (Source: Google Photo).

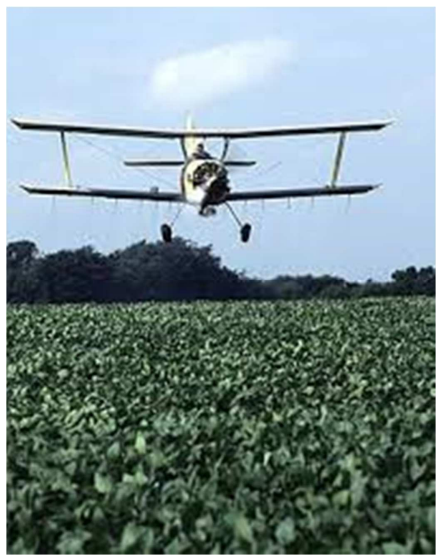

Figure 12. Aerial Pest Control System (Source: Google Photo).

\section{Deterioration of Pasture, Range Land and Grazing Reserves}

Pasture, range and grazing reserve deterioration normally occurs over time, even though it may, sometimes, appear to happen suddenly. Good grazers routinely walk their pastures, looking for changes in populations of desirable plants, increases in weeds, loss of plant vigour, and increasing bare spots. If a pasture manager is not watching closely and allows animals to continue to graze plants to ground level during hot, dry conditions, the grass can be eliminated completely from the pasture $[13,7]$.

Walking pastures in wet and dry seasons will, also, allow you to develop an inventory of weeds that are present. Continual grazing combined with slow dry season forage growth creates bare spots, allowing sunlight to reach the soil surface. This creates a wonderful opportunity for weed seeds to germinate and for weeds to become established. Herbicides today are very safe if properly used but are selective and are not always effective on all the weeds that are present. It is important to choose the best herbicide to control the weeds that are in the pastures and equally important to use that product at the right time [13].

Rotating pastures will allow grasses to recover and will keep pasture productive. Tall grasses can be grazed to maintain a height of 4-5 inches; short grasses should be maintained at 2 to 3 inches. If grass is grazed lower than this, the animals should be removed from the pasture and rotated to another pasture. If there is not enough land on the farm to allow for rotation, then stress lots or sacrifice areas can be constructed to contain animals during periods of adverse growing conditions [13].

Stress lots are generally constructed of small stone and then covered with packed stone dust so that manure can be scraped from the surface. The lot is sloped to allow water to run off. Vegetation should be maintained around the stress lot to absorb water and excess nutrients [13].

\subsection{Over-grazing}

Over-grazing represents an environmental hazard whereby livestock excessively feed on pasture. It is, also, the practice of grazing livestock on vegetation before it has recovered from a former grazing state, also known as intensive grazing. Otherwise stated, over-grazing takes place when vegetation or pasture is repeatedly removed from land and it is not given enough time to continue growing or regenerate $[13,7]$.

Intensive grazing thus causes the plant residual matter to decline and further contributes to numerous negative consequences to both the animals and the land [13]. Consequently, over-grazing signifies a serious environmental challenge in maintaining the natural balance of livestock on grazing lands, which eventually reduces the productivity, usefulness, and bio-diversity of the land (Figures 13 and 14).

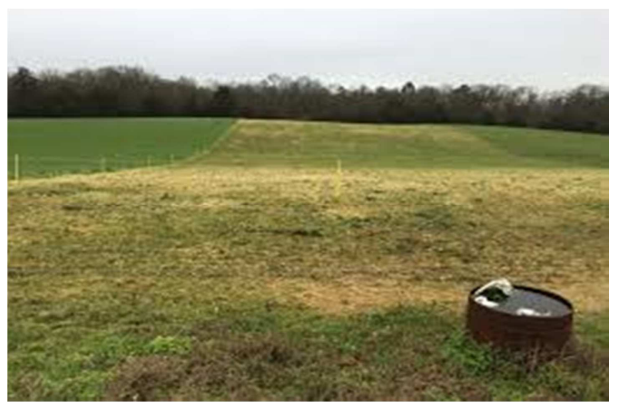

Figure 13. Sign of Over-grazing (Source: Google Photo).

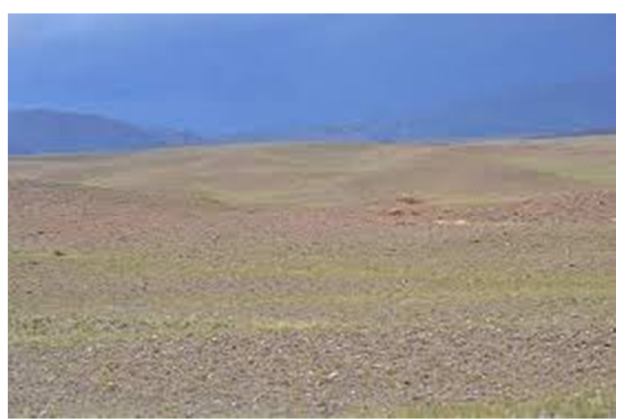

Figure 14. Over-grazed Pasture Land (Source: Google Photo).

\subsection{Causes of Over-grazing}

Lack of proper animal feeding management on the available pasture is the leading cause of over-grazing. From the definition, over-grazing arises as a result of having too many animals grazing on a piece of land without considering the carrying capacity of the land [13]. Another cause is the failure to rotate animals in harmony with pasture growth [13].

For instance, without proper management of the animals' 
feeding habits, they tend to feed on young plants and seeds, thereby reducing their growth and survival capacities. Besides, lack of proper animal grazing management negatively affects the soil's nutrient composition which further worsens the situation $[13,7]$.

Also, drought or decline in precipitation in any area automatically means that, the growth and survival of plants and vegetation is heavily impacted. The direct outcome of this is stunted growth and drying out of plants/vegetation. Accordingly, the risk of over-grazing is heightened in such areas subject to insufficiency of forage. Examples include areas adjacent to deserts such as Northern Nigeria, China, Pakistan, India, Patagonia, the drier regions of Southern and Northern Africa, and the prairies of Northern America [20, 13, $15]$.

Improper land use, also, causes over-grazing. Land use significantly determines the productive condition of the land and soil fertility. Hence, improper land use such as logging activities, slash and burn farming techniques, mining, excessive and unplanned urban sprawl, and land pollution lessen the overall land available for pasture. All these activities greatly impact the availability of plants and forage by destroying their underlying growth support mechanisms. In most cases, these activities are characterized by increase in unpalatable plants or weeds and decrease in soil humus and this increases the potential of the over-grazing problem [15].

Over-stocking implies a situation where a piece of land is intensively stocked with more animals than the site can support for a grazing season. In majority of the cases, animals are more than the average land available for grazing, which leads to repeated removal of plant/vegetation material without sufficient amount of time given for the leaf/pasture mass to re-grow. Farmers who over-stock do not let the average land replenish itself after a previous grazing season and eventually, over-grazing is experienced $[13,7]$.

Incorrect irrigation techniques in arid and semi-arid regions cause accumulation of salt in the soil. As an outcome, the availability of palatable plants is impacted because of alteration of the soil's mineral content composition. The build-up of salts in the soil, also, leads to stunted growth, thereby reducing the availability of forage. The few remaining good pasture lands are hence heavily utilized, creating room for over-grazing. The problem is further exacerbated by the fact that, poor irrigation practices are common in poorer regions $[6,15]$.

\subsection{Effects of Over-grazing}

The continued trampling of numerous animals on an average forage land accelerates the death of plants and vegetation cover. This is because the animals will graze even on the slightest shoots of new growth. Without the plants or vegetation cover, the soil is left bare and exposed to harsh weather, such as heavy downpour and high temperatures, which disintegrates the rocks and erode the top soil. Animals, also, prefer gathering at specific areas, especially near to water sources, and such areas can get eroded easily $[13,7]$.

The acts of compaction and erosion as a result of over- grazing can cause tremendous land degradation. In drier areas, the experience is even worse as a large percentage of pasture and land cover is destroyed, contributing to relentless progression of desertification. In fact, in some areas, overgrazing has led to complete desertification. Over-grazing combined with over-stocking has the most damaging outcomes to the world's natural environment [20, 13, 15].

The scarcity of water resources, water pollution, degeneration of coral reefs, and eutrophication are all connected to over-grazing [7]. The chief polluting elements include farm chemicals and animal wastes. Intensive grazing disrupts the water cycle and diminishes the replenishment capability of ground water resources as substantial amounts of water is used for feed production. In the South China Sea, over-grazing is linked with nitrogen and phosphorous contamination.

The natural composition of plant population and their regeneration capacity is significantly affected by overgrazing. The original pasture crops are composed of high quality pastures and herbs with great nutritional value. When animals intensively graze on such pastures, even the root stocks which contain the reserve food or regeneration capacity get ruined. Once this happens, some other more adaptable species such as weeds and unpalatable plants take up their place. These secondary plant species have less nutritional values and because they are highly adaptive, they replace the native species, thereby causing the loss of valuable plant species [15].

As earlier stated, over-grazing is a primary contributor to desertification because it converts arable or pasture land into unproductive piece of land. The resultant soil is, thus, not suited for growing food or pasture, since it loses its essential nutrients due to erosion. The loss of land productivity directly results in the loss of food or forage available for human and animal consumption. This heightens food or pasture supply reduction and if population growth is still registered, it eventually leads to starvation and economic challenges [6, 20, 13, 15].

The long term effects of over-grazing are food or pasture shortage, which can make people and cattle die of starvation. Without sufficient pasture for livestock grazing, cattle lack the necessary nutrients for survival. The nutrient deficiencies make the animals unable to gain weight appropriate for their productive stage and life which lowers their chances of survival. Human survival levels, well-being, and health are as well affected when there is inadequate food or forage supply for livestock consumption. The end results are acute starvation and death of both people and livestock $[13,15]$.

\subsection{Solutions to Over-grazing}

As much as over-grazing is associated with the number of animals, the solution is more about the management of the animals. There are several methods of grazing management to choose from that can offer effective solutions to overgrazing. Examples are rotational, cell, and mob grazing. It is the responsibility of those in charge of grazing to take appropriate measures in ensuring that these management 
practices are effectively utilized $[13,7]$.

Each grazing management technique is tailored to meet different situation and if well utilized, it can strongly assist in restoring the plant growth during the entire year. Proper management of animals, also, bears the potential of wholly enhancing grazing land conditions via improved pasture production and soil fertility [7].

Land use management involves the proper assessment of various land uses and the implications of human activities on land. Local and regional factors such as aridity and rainfall patterns, also, have to be considered before any land development or exploitation implementations are undertaken. Proper urban planning and industry set-up has to be in accordance with up-to-date environmental policies on sustainable urbanization, industry construction, and agricultural practices [7].

This eliminates the over-utilization of available arable land and green pastures and enables easier control policies on over-stocking. Use of soil conservation measures and silvopastoralism, in conjunction with controlled livestock restriction from sensitive areas and payment schemes for livestock-based land use can, also, help cut down and reverse the effects of over-grazing [7].

Sustainable pasture practices pertain to grass-land production in a well-managed and controlled manner [7]. The concept is simply based on grass-land management, animal management and livestock marketing. When grazing management is combined with agro-ecological practices and sustainable agriculture, it gives rise to the most suitable grass-land-based livestock production because it encourages both animal and plant productivity and good health. Some of the novel and impressive sustainable grazing models and management systems that try to lessen or end over-grazing include permaculture and holistic livestock management.

\section{Conclusion and Recommendations}

The purpose of pasture, range and grazing reserves management are to provide all year round uniform and highly nutritive forage for a maximum number of animals; maintain a favourable balance between the species established; use the forage crops at short stages as may be permitted, so as to combine nutritive quality and high yield; maintain the pasture, range land and grazing reserves in their most productive condition all the time; encourages best species in the mixture and promotes uniform coverage of the soil surface; species must be capable of controlling weeds and erosion; regulate stocking rates to obtain maximum returns from the animals. Provide for rest period so as to allow the forage to recover; achieve high annual economic returns.

In order to achieve these goals, the following have to be considered; influence of seasonal growth on grazing operations should be adjusted to fit seasonal trends of growth and grazing; variation in composition and feeding value of herbage in relation to stage of growth; it should be cut and grazed when nutritive value is very high in terms of both nutrients level and palatability; system of animal management must be considered.
Stocking rate should be adequate to maintain vigorous growth of pasture species; light, temperature and moisture are environmental factors that influence vegetative growth and should be considered; biennial and perennial crops tend to store reserves in their roots and rhizomes so that, in early stages of growth, there is mobilization of reserves to the storage tissues. However, they should have enough time to accumulate reserves; too frequent grazing is dangerous to the plants; under frequent cutting, plants become susceptible to droughts, pests and diseases; cut or graze pasture just before flowering and seed set; there is maximum accumulation of dry matter combined with nutritive values of the forage plants at this stage; over-grazing and under-grazing is injurious to plants and should be avoided.

\section{Acknowledgements}

All the literatures consulted are dully acknowledged and figures used in this paper are that of the internet photos.

\section{References}

[1] Adjolohoun, S., Bindelle, J., Adandédjan, C., \& Buldgen, A. (2008). Some Suitable Grasses and Legumes for Ley Pastures in Sudanian Africa: The Case of the Borgou Region in Benin. Biotechnol. Agron. Soc. Environ., 12 (4), 405-419.

[2] Allen, V. G., \& Collins. M. (2003). Grazing management systems. Pp. 473-501. In R. F Barnes et al. (ed.) Forages: An introduction to grassland agriculture. 6th ed. Iowa State Press, Ames, IA.

[3] Allen, V. G., Heitschmidt, R. K., \& Sollenberger, L. E. (2007) Grazing systems and strategies. Pp. 709-729. In R. F Barnes et al. (ed.) Forages: The science of grassland agriculture. 6th ed. Blackwell, Ames, IA.

[4] Amanullah, M. M., Somasundaram, E., Alagesan, A., Vaiyapuri, K., Pazhanivelan, S., \& Sathyamoorthi, K. (2006). Evaluation of Some Tree Species for Leaf Fodder in Tamil Nadu. Res. J. Agric. Biol. Sci., 2 (6), 552-553.

[5] Barker, D. J., \& Collins, M. (2003). Forage fertilization and nutrient management. Pp. 263-293. In R. F Barnes et al. (ed.) Forages: An introduction to grassland agriculture. 6th ed. Iowa State Press, Ames, IA.

[6] Barnhart, S. K. (2004). Steps to establish and maintain legume-grass pastures. Iowa State University Extension, Agronomy 3-3. Ames, IA.

[7] Belay, Z. (2015). Rangeland degradation and restoration: A global perspective. Point Journal of Agriculture and Biotechnology Research, 1 (2), 037-054.

[8] Bradley, K., Kallenbach, R., \& Roberts, C. A. (2010). Influence of seeding rate and herbicide treatments on weed control, yield and quality of spring-seeded glyphosateresistant alfalfa. Agron. Journal, 102, 751-758.

[9] Cook, B. G., Pengelly, B. C., Brown, S. D., Donnelly, J. L., Eagles, D. A., Franco, M. A., Hanson, J., Mullen, B. F., Partridge, I. J., Peters, M., \& Schultze-Kraft, R. (2005). Tropical Forages. CSIRO, DPI \& F (Qld), CIAT and ILRI, Brisbane, Australia. 
[10] FMAWR (2008). Federal Ministry of Agriculture and Water Resources, Federal Republic of Nigeria, Draft National Security Programme, Pp. 107.

[11] Humphreys, L. R. (1999). Tropical Pastures and Fodder Crops (2nd ed.); Intermediate Tropical Agricultural Series. (Ed. W. J. A. Payne), Longman Science \& Technical, U. K. Pp. 155.

[12] Kallah, M. S. (2004). Rangelands in Nigeria: A Partial Resource Appraisal Towards Improving Livestock Production. In: Forage Production and Management in Nigeria, eds. J. O. Gefu and J. T. Amodu, National Animal Production Research Institute. Ahmadu Bello University, Zaria, Nigeria, Pp. 1-10.

[13] Khobe, D. (2011). Species composition and range condition of Jibiro Grazing Reserve, Adamawa State, Nigeria. Global Journal of Science Frontier Research, 11 (9), 21-24.

[14] Murphy, S. (2010). Tropical Perennial Grasses - Root Depths, Growth and Water Use Efficiency. NSW Industry and Investment, Primefacts $\mathrm{N}^{\circ} 1027$.

[15] Nweze, B. O., Ekwe, O. O., Alaku, S. O., \& Omeje, S. I. (2012). Productivity of two indigenous Nigerian cattle breeds and their crossbred under range grazing management. World Journal of Life Sci. and Medical Research, 2 (1), 1-8.

[16] Obua, B. E., McAlbert, F. U., Okoro, B. O., \& Efrenie, S.
(2012). Survey of the Diversity of Forage Plants Used in Feeding Pigs in Small-holder Farms in South-Eastern Nigeria. Int. J. Agric. Rural Dev., 15 (3), 1310-1316.

[17] Okorie, A. U. (1992). Pasture and pastoral development in Nigeria, In: The Nigerian Livestock Industry: Problems and Prospects. In the Proceedings of the Workshop on Proposed Livestock, sub-sector Review, by Livestock Planning, Monitoring, Evaluation and Coordinating Unit (LIMECU), Abuja, Nigeria, on 26-27 February, Pp. 38-44.

[18] Okorie, A. U., \& Sanda, L. U. (1992). Rangeland and grazing reserve in Nigeria: Livestock sub-sector review. FAO (Food and Agriculture Organization), Rome, 2, 2-15.

[19] Olivo, C. J., Aguirre, P. F., Araujo, T. L. da R. de, Diehl, M. S., Bem, C. M. de, Serafim, G., \& Correa, M. da R. (2013). Productivity and Crude Protein of Elephant Grass Pastures Managed under Agro-Ecological and Conventional Systems. Ciencia Rural, 43 (8), 1471-1477.

[20] Shiawoya, E. L., \& Tsado D. N. (2011). Forage and fodder crop production in Nigeria: Problems and prospects. World Journal of Life Sci. and Medical Research, 1 (4): 88.

[21] Skerman, P. J., \& Riveros, F. (1990). Tropical Grasses. FAO Plant Production and Protection Series No. 23, FAO, Rome. 